\title{
Taxonomic rearrangements of the genera Thiocapsa and Amoebobacter on the basis of 165 rDNA sequence analyses, and description of Thiolamprovum gen. nov.
}

\author{
Rémy Guyoneaud, ${ }^{1}$ Jörg Süling, ${ }^{2}$ Ralf Petri, ${ }^{2}$ Robert Matheron, ${ }^{3}$ \\ Pierre Caumette, ${ }^{1}$ Norbert Pfennig ${ }^{4}$ and Johannes F. Imhoff ${ }^{2}$
}

Author for correspondence: Johannes F. Imhoff. Tel: +49 431597 3850. Fax: +49 431565876. e-mail: jimhoff@ifm.uni-kiel.de

\footnotetext{
1 Laboratoire d'Océanographie Biologique, Université Bordeaux I, URA-CNRS 197, 2 rue du Professeur Jolyet, F-33120 Arcachon, France

2 Institut für Meereskunde an der Universităt Kiel, Abteilung Marine Mikrobiologie, Düsternbrooker Weg 20 , D-24105 Kiel, Germany

3 Laboratoire de Microbiologie, Faculté des Sciences et Techniques de Saint- Jérome, F-13397 Marseille Cedex 20, France

4 Primelweg 12, D-88662, Überlingen, Germany
}

\begin{abstract}
Complete nucleotide sequences of the 165 rDNAs were determined from Thiocapsa and Amoebobacter species, including all available type strains and some additional isolates. The distance-matrix analysis and the dendrogram for estimating the genetic relationships revealed that the investigated strains were found in two major clusters within the Chromatiaceae. One cluster comprises all Amoebobacter species, Thiocapsa roseopersicina and several isolates related to Thiocapsa roseopersicina. Representatives of the species Amoebobacter roseus, Amoebobacter pendens and Thiocapsa roseopersicina, the so called 'Thiocapsa roseopersicina group', are very closely related, justifying their inclusion into one genus, Thiocapsa, for which an emended description is presented. Amoebobacter purpureus and Amoebobacter pedioformis formed two separate lines of descent with less than $93 \%$ (89.6-92.9\%) similarity to strains of the 'Thiocapsa roseopersicina group'. Therefore, they will be considered as two separate genera. As a consequence, an emended description is presented for the genus Amoebobacter, with Amoebobacter purpureus as the new type species and A. pedioformis is transferred to Thiolamprovum pedioforme gen. nov., comb. nov. Two species, Thiocapsa pfennigii and Thiocapsa halophila, which have been classified with the genus Thiocapsa because of their morphological properties, were found within another major cluster of the Chromatiaceae and are only distantly phylogenetically related to the first cluster with 88.4-90.6 \% and $90.4-92.2 \%$ sequence similarity, respectively.
\end{abstract}

Keywords: Thiocapsa, Amoebobacter, Thiolamprovum, Chromatiaceae, 16S rDNA sequences, genetic relationships, taxonomy

\section{INTRODUCTION}

Classification of Chromatiaceae (Bavendamm 1924, emend. Imhoff 1984) has been inherited from the morphological studies of Winogradsky (1888) and is still principally based on phenotypic characteristics. The first studies to establish genetic relationships of Chromatiaceae species were carried out on the basis of 16S rRNA oligonucleotide cataloguing (Fowler et al., 1984). They demonstrated that these bacteria are

The EMBL accession numbers for the sequences reported in this paper are indicated in Table 1 and Fig. 1. moderately related but form a coherent phylogenetic group for which the family name Chromatiaceae is justified. They also revealed strong discrepancies between phylogenetic relatedness and the taxonomic system of the family, based on phenotypic traits. Their study demanded more detailed investigations on the phylogenetic relationships within this family to establish a proper basis for a phylogenetically oriented taxonomy.

The first complete 16S rDNA sequences among the Chromatiaceae were obtained for Chromatium vinosum (De Weerd et al., 1990) and Chromatium tepidum (Wahlund et al., 1991). Recently, with the description 
Table 1. Species and strains sequenced in this study

\begin{tabular}{|c|c|c|c|c|c|}
\hline Previous name & New name & DSM no. & $\begin{array}{c}\text { Original } \\
\text { designation }\end{array}$ & $\begin{array}{c}\text { EMBL } \\
\text { accession no. }\end{array}$ & Reference \\
\hline Thiocapsa roseopersicina & Thiocapsa roseopersicina & $\operatorname{DSM} 217^{\mathrm{T}}$ & 1711 & Y12364 & $\begin{array}{l}\text { Pfennig (1989a, b), Pfennig \& } \\
\text { Trüper (1971a, b) }\end{array}$ \\
\hline 'Thiocapsa roseopersicina' & Thiocapsa sp. & - & 9314 & Y12303 & Mandel et al. (1971)* \\
\hline 'Thiocapsa roseopersicina' & Thiocapsa sp. & - & 10511 & Y12300 & Guyoneaud et al. (1997) $\dagger$ \\
\hline 'Thiocapsa roseopersicina' & Thiocapsa sp. & - & CE2209 & Y12298 & Guyoneaud et al. (1996) \\
\hline 'Thiocapsa roseopersicina' & Thiocapsa sp. & DSM 5653 & 5811 & Y12301 & Caumette et al. (1985) \\
\hline 'Thiocapsa roseopersicina' & Thiocapsa sp. & - & 5812 & Y12302 & Caumette (1986) \\
\hline Thiocapsa halophila & Uncertain affiliation & DSM $6210^{\mathrm{T}}$ & SG3202 & AJ002796 & Caumette et al. (1991) \\
\hline Thiocapsa pfennigii & Uncertain affiliation & DSM 226 & 8013 & Y12373 & Mandel et al. (1971)* \\
\hline Amoebobacter pendens & Thiocapsa sp. & DSM 5652 & 5813 & Y12396 & Caumette et al. (1985) \\
\hline Amoebobacter pendens & Thiocapsa pendens & DSM $236^{\mathrm{T}}$ & 1314 & AJ002797 & $\begin{array}{l}\text { Pfennig }(1989 a, b), \text { Pfennig \& } \\
\text { Trüper }(1971 a, b)\end{array}$ \\
\hline Amoebobacter roseus & Thiocapsa rosea & DSM $235^{\mathrm{T}}$ & 6611 & AJ002798 & $\begin{array}{l}\text { Pfennig }(1989 \mathrm{a}, \mathrm{b}) \text {, Pfennig } \& \\
\text { Trüper (1971a, b) }\end{array}$ \\
\hline Amoebobacter purpureus & Amoebobacter purpureus & DSM $4197^{\mathrm{T}}$ & ThSchl2 & Y12366 & Eichler \& Pfennig (1988) \\
\hline Amoebobacter pedioformis & Thiolamprovum pedioforme & DSM $3802^{\mathrm{T}}$ & CML2 & Y12297 & Eichler \& Pfennig (1986) \\
\hline
\end{tabular}

* These strains have not been described phenotypically in the literature.

† Reference for 16S rDNA sequence.

$\ddagger$ Tentatively designated as Thiocapsa roseopersicina forma specialis by Caumette et al. (1985).

of the new genera and species Rhabdochromatium marinum (Dilling et al., 1995), Chromatium glycolicum (Caumette et al., 1997) and Thiorhodococcus minus (Guyoneaud et al., 1997), more 16S rDNA sequences became available, which confirmed the non-phylogenetic nature of the phenotypic classification of the Chromatiaceae (Guyoneaud et al., 1997).

The genera Thiocapsa and Amoebobacter comprise the spherical and non-motile representatives of the Chromatiaceae. The differentiation between the two genera is based on the presence or absence of gas vesicles. In the case of Ectothiorhodospiraceae (Imhoff \& Süling, 1996) and green sulfur bacteria (Overmann \& Tuschack, 1997), the possession of gas vesicles is not considered to be of taxonomic relevance at the genus level. Moreover, the study based on 16S rRNA oligonucleotide cataloguing (Fowler et al., 1984) had already revealed that some species of these two genera (Thiocapsa roseopersicina, Amoebobacter pendens and Amoebobacter roseus) are very closely related $\left(S_{\mathrm{AB}}\right.$ values $\geqslant 0.93$ ) and may actually comprise species of a single genus. Since this work, several new species have been described for both genera: Amoebobacter pedioformis (Eichler \& Pfennig, 1986), Amoebobacter purpureus (Eichler \& Pfennig, 1988) and Thiocapsa halophila (Caumette et al., 1991). In addition, strains resembling Thiocapsa roseopersicina but containing okenone instead of spirilloxanthin as the major carotenoid were isolated (Caumette et al., 1985). These new isolates were described and classified according to their phenotypic traits. Their genetic relationships have not been investigated so far. We have analysed the $16 \mathrm{~S}$ rDNA sequences of the known species of the genera
Thiocapsa and Amoebobacter (including all available type strains) and propose a taxonomic rearrangement at the genus level.

\section{METHODS}

Source and culture of bacterial strains. All Thiocapsa and Amoebobacter strains used for this study are listed in Table 1, which shows the previously used and the newly proposed names, the original strain designations, the DSM numbers (where available) and the EMBL accession numbers for their 16S rDNA sequences. Cultures of all strains are now maintained in our laboratories (see Table 1).

Strains were cultivated in a synthetic medium prepared anaerobically according to Pfennig \& Trüper (1992). The medium contained: $0.03 \% \quad \mathrm{KH}_{2} \mathrm{PO}_{4} ; 0.05 \% \quad \mathrm{NH}_{4} \mathrm{Cl}$; $0.005 \% \quad \mathrm{CaCl}_{2} .2 \mathrm{H}_{2} \mathrm{O} ; \quad 0.1 \% \quad \mathrm{MgCl}_{2} .6 \mathrm{H}_{2} \mathrm{O} ; \quad 0.05 \%$ $\mathrm{MgSO}_{4} .7 \mathrm{H}_{2} \mathrm{O} ; 1 \mathrm{ml}$ trace-element solution SL12 ${ }^{-1}$ (Pfennig \& Trüper, 1992); $0.02 \mathrm{mg}$ vitamin $\mathrm{B}_{12} \mathrm{I}^{-1} ; 0.15 \%$ $\mathrm{NaHCO}_{3} ; 0.05 \% \mathrm{Na}_{2} \mathrm{~S} .9 \mathrm{H}_{2} \mathrm{O}$; final pH, 7.2. In addition, for some strains, $2 \% \mathrm{NaCl}$ [strains 5811(=DSM 5653), 5812, 5813 (=DSM 5652), CE2209] or $6 \% \mathrm{NaCl}$ (strain DSM 6210 ) was added to the medium. Pure cultures were grown and maintained in $50 \mathrm{ml}$ screw-capped bottles filled with synthetic medium.

PCR amplification and 16S rDNA sequencing and analysis. DNA for sequencing of 16S rRNA genes was obtained either from 1-2 $\mathrm{ml}$ well-grown liquid cultures or from freeze-dried material ( $A$. pedioformis DSM 3802, $A$. roseus DSM 235 and $A$. pendens 5813 ). DNA was extracted and purified by using the QIAGEN genomic DNA buffer set. Recombinant Taq DNA polymerase was used for PCR (Mullis \& Faloona, 1987) with the primers: 5'-GTTTGATCCTGGCTCAG-3' and 5'-TACCTTGTTACGACTTCA-3' (positions 11-27 and 1489-1506, respectively; according to the Escherichia 
coli 16S rRNA numbering of the International Union of Biochemistry). The PCR products were purified by using the QIAquick PCR purification kit. Sequences were obtained by cycle sequencing with the SequiTherm sequencing kit (Biozym) and the chain termination reaction (Sanger et al., 1977) using an automated laser fluorescence sequencer (Pharmacia). Sequences were aligned using the CLUSTAL w program (Thompson et al., 1994). The alignment was from position 29-1381 according to the Escherichia coli numbering (including gaps, approx. 1400 positions). The distance matrix was calculated on the basis of the algorithm according to Jukes \& Cantor (1969) with the DNADIST program within the PHYLIP package (Felsenstein, 1989). The FITCH program in the PHYLIP package fitted a tree to the evolutionary distances.

\section{RESULTS AND DISCUSSION}

Sequences of $16 \mathrm{~S}$ rDNA from a number of strains of Thiocapsa and Amoebobacter species were determined, aligned and compared to those of other Chromatiaceae, Ectothiorhodospira shaposhnikovii, Halorhodospira halophila and Escherichia coli, which were available from the EMBL database. Sequence similarity and evolutionary distances ( $K_{\text {nuc }}$ values) are presented in Table 2; a dendrogram calculated on the basis of these values is shown in Fig. 1. The 16S rDNA gene sequence analysis confirmed that the representatives of the genera Thiocapsa and Amoebobacter are true members of the Chromatiaceae, placed within the gamma-Proteobacteria. Within the radiation of the family Chromatiaceae, the strains investigated were found in two clusters. Most of the strains formed one distinct cluster, which was not distinctly affiliated with one of the available reference organisms from this family (see Fig. 1). This cluster comprises all Amoebobacter species, Thiocapsa roseopersicina and strains related to this latter species. The analysis suggests a common ancestor of all of these strains and of Chromatium vinosum and related species. Two species were found within a second cluster, which includes 'Thiocapsa pfennigii' and 'Thiocapsa halophila' as well as Rhabdochromatium marinum and other marine Chromatiaceae.

Within the first cluster, Thiocapsa roseopersicina, $A$. roseus and $A$. pendens formed a closely related group (in the following referred to as the "Thiocapsa roseopersicina group') with a minimum of $93.9 \%$ sequence similarity between the strains included in this study. These results are in agreement with the previous studies on 16S rRNA oligonucleotide cataloguing (Fowler et al., 1984), which already recognized the close relationship of these species $\left(S_{\mathrm{AB}}\right.$ value of 0.93$)$. Amoebobacter purpureus and A. pedioformis, however, formed two different lineages separated from the representatives of the "Thiocapsa roseopersicina group'. The sequence similarity between $A$. purpureus, A. pedioformis and all the other strains of this cluster was 89.6-91.9 and 88.9-92.9\%, respectively. Moreover, the sequence similarity between $A$. purpureus and $A$. pedioformis was $88.9 \%$, suggesting that these two species belong to two separate genera.

First of all, these results demonstrate a large phylogenetic distance between presently recognized species

Table 2. Levels of $16 \mathrm{~S}$ rDNA sequence similarity and evolutionary distances of presently recognized Thiocapsa and Amoebobacter species with other phototrophic purple sulfur bacteria and Escherichia coli as reference species.

Alignment length was 1400 positions including gaps (bases 29-1381, according to Escherichia coli numbering). All strains were fitted to that size except for 'Thiocapsa roseopersicina', DSM 217 (positions 69-1363 according to Escherichia coli numbering) and A. roseus, DSM 235 (positions 71-1374 according to Escherichia coli numbering). The values on the upper right are the uncoriected percentages of sequence similarity; the values on the lower left are $K_{\text {nuc }}$ values corrected for multiple base change by the method of Jukes \& Cantor (1969).

\begin{tabular}{|c|c|c|c|c|c|c|c|c|c|c|c|c|c|c|c|c|c|c|c|c|}
\hline \multirow[t]{2}{*}{ Organism } & \multicolumn{20}{|c|}{ Sequence similarity $(\%)$ and evolutionary distance $\left(K_{\text {nuc }}\right)$} \\
\hline & 1 & 2 & 3 & 4 & 5 & 6 & 7 & 8 & 9 & 10 & 11 & 12 & 13 & 14 & 15 & 16 & 17 & 18 & 19 & 20 \\
\hline 1 Thiocapsa pfennigii DSM $226^{T}$ & & $93 \cdot 1$ & 91.8 & $90 \cdot 4$ & $89 \cdot 9$ & $89 \cdot 3$ & $90 \cdot 5$ & $90 \cdot 4$ & $89 \cdot 9$ & $89 \cdot 3$ & $90 \cdot 3$ & $90 \cdot 5$ & 90.0 & $90 \cdot 6$ & $88 \cdot 4$ & $88 \cdot 8$ & $89 \cdot 4$ & $86 \cdot 9$ & $85 \cdot 1$ & $82 \cdot 9$ \\
\hline 2 Thiocapsa halophila DSM $6210^{\mathrm{T}}$ & 0.073 & & $94 \cdot 5$ & $92 \cdot 4$ & $92 \cdot 2$ & $90 \cdot 8$ & $91 \cdot 7$ & $91 \cdot 1$ & $91 \cdot 1$ & $90 \cdot 4$ & $92 \cdot 2$ & 92.0 & $92 \cdot 1$ & $92 \cdot 2$ & $91 \cdot 1$ & $91 \cdot 5$ & $91 \cdot 5$ & $89 \cdot 9$ & $87 \cdot 2$ & $84 \cdot 2$ \\
\hline 3 Rhabdochromatium marinum DSM $5261^{\mathrm{T}}$ & 0.087 & 0.057 & & $90 \cdot 4$ & $91 \cdot 2$ & 89.9 & $91 \cdot 6$ & $91 \cdot 0$ & $90 \cdot 9$ & $90 \cdot 4$ & $91 \cdot 6$ & $91 \cdot 4$ & $91 \cdot 4$ & $92 \cdot 2$ & $89 \cdot 9$ & $91 \cdot 7$ & $92 \cdot 3$ & $89 \cdot 2$ & 86.8 & $84 \cdot 6$ \\
\hline 4 Chromatium gracile $\mathrm{DSM} 203^{\mathrm{T}}$ & $0 \cdot 103$ & 0.081 & $0 \cdot 103$ & & $92 \cdot 5$ & $90 \cdot 5$ & 90.6 & $90 \cdot 8$ & $90 \cdot 1$ & $89 \cdot 1$ & $90 \cdot 6$ & $90 \cdot 7$ & $90 \cdot 6$ & $90 \cdot 9$ & $90 \cdot 1$ & $89 \cdot 0$ & $90 \cdot 9$ & $88 \cdot 8$ & $86 \cdot 6$ & $83 \cdot 6$ \\
\hline 5 Chromatium vinosum DSM $180^{\mathrm{T}}$ & $0 \cdot 108$ & 0.083 & 0.094 & 0.079 & & $91 \cdot 8$ & $92 \cdot 2$ & $91 \cdot 0$ & $91 \cdot 1$ & $91 \cdot 0$ & $92 \cdot 5$ & $92 \cdot 4$ & $92 \cdot 4$ & $92 \cdot 8$ & $89 \cdot 9$ & $90 \cdot 7$ & $94 \cdot 3$ & $89 \cdot 4$ & $86 \cdot 6$ & $84 \cdot 3$ \\
\hline 6 Thiocapsa roseopersicina DSM $217^{\mathrm{T}}$ & 0.116 & 0.098 & $0 \cdot 109$ & $0 \cdot 101$ & $0 \cdot 086$ & & 95.9 & 94.9 & $94 \cdot 0$ & $94 \cdot 3$ & $95 \cdot 0$ & $95 \cdot 5$ & 96.1 & $96 \cdot 0$ & $90 \cdot 1$ & $91 \cdot 3$ & $91 \cdot 3$ & $87 \cdot 1$ & $85 \cdot 2$ & $82 \cdot 7$ \\
\hline 7 Thiocapsa roseopersicina 9314 & $0 \cdot 101$ & 0.088 & 0.089 & $0 \cdot 100$ & $0 \cdot 082$ & 0.042 & & $95 \cdot 8$ & $94 \cdot 8$ & $95 \cdot 1$ & $96 \cdot 3$ & $96 \cdot 3$ & $95 \cdot 7$ & $96 \cdot 4$ & $90 \cdot 9$ & $92 \cdot 4$ & $92 \cdot 4$ & $88 \cdot 7$ & 86.4 & $83 \cdot 4$ \\
\hline 8 Amoebobacter pendens DSM $236^{\mathrm{T}}$ & $0 \cdot 103$ & 0.095 & 0.095 & 0.098 & 0.096 & 0.053 & 0.043 & & $94 \cdot 9$ & $94 \cdot 5$ & $95 \cdot 7$ & 95.9 & $95 \cdot 5$ & 95.8 & $91 \cdot 9$ & $91 \cdot 1$ & 91.8 & $88 \cdot 2$ & $85 \cdot 0$ & $82 \cdot 7$ \\
\hline 9 Amoebobacter pendens DSM 5652 & 0.108 & 0.095 & 0.097 & $0 \cdot 106$ & 0.095 & $0 \cdot 062$ & 0.054 & 0.053 & & 93.9 & $95 \cdot 8$ & 95.9 & $95 \cdot 7$ & $95 \cdot 6$ & $90 \cdot 9$ & 91.0 & $91 \cdot 6$ & $87 \cdot 4$ & 84.9 & 82.5 \\
\hline 10 Amoebobacter roseus DSM $235^{\mathrm{T}}$ & $0 \cdot 116$ & $0 \cdot 102$ & $0 \cdot 103$ & 0.118 & 0.096 & $0 \cdot 059$ & 0.051 & 0.057 & $0 \cdot 064$ & & $94 \cdot 7$ & 94.8 & $95 \cdot 2$ & $95 \cdot 9$ & $89 \cdot 6$ & $91 \cdot 4$ & $91 \cdot 2$ & $87 \cdot 7$ & $84 \cdot 7$ & $82 \cdot 8$ \\
\hline 11 'Thiocapsa roseopersicina' DSM 5653 & $0 \cdot 104$ & 0.083 & 0.089 & $0 \cdot 100$ & 0.079 & $0 \cdot 051$ & 0.038 & 0.045 & 0.043 & 0.055 & & $98 \cdot 5$ & $97 \cdot 4$ & $97 \cdot 4$ & $91 \cdot 2$ & $91 \cdot 9$ & $92 \cdot 5$ & $89 \cdot 2$ & $86 \cdot 3$ & $83 \cdot 7$ \\
\hline 12 'Thiocapsa roseopersicina' 5812 & $0 \cdot 102$ & 0.084 & 0.091 & $0 \cdot 100$ & $0 \cdot 080$ & 0.047 & 0.038 & 0.042 & 0.042 & 0.054 & 0.015 & & $97 \cdot 3$ & $97 \cdot 6$ & $91 \cdot 5$ & $92 \cdot 0$ & $92 \cdot 1$ & $89 \cdot 0$ & $85 \cdot 8$ & $83 \cdot 1$ \\
\hline 13 'Thiocapsa roseopersicina' 10511 & 0.108 & 0.084 & 0.092 & $0 \cdot 101$ & 0.080 & 0.040 & 0.044 & 0.047 & 0.044 & 0.049 & 0.027 & 0.027 & & 97.4 & $91 \cdot 3$ & 91.8 & $92 \cdot 4$ & 88.8 & $85 \cdot 5$ & $83 \cdot 5$ \\
\hline 14 'Thiocapsa roseopersicina' CE2209 & $0 \cdot 101$ & 0.082 & 0.083 & 0.097 & 0.076 & 0.042 & 0.037 & 0.043 & 0.045 & 0.042 & 0.026 & 0.024 & 0.027 & & $91 \cdot 0$ & $92 \cdot 9$ & $92 \cdot 6$ & $89 \cdot 4$ & $86 \cdot 5$ & $84 \cdot 5$ \\
\hline 15 Amoebobacter purpureus DSM $4197^{\mathrm{T}}$ & 0.126 & 0.095 & $0 \cdot 109$ & 0.106 & $0 \cdot 108$ & $0 \cdot 107$ & 0.097 & 0.085 & 0.097 & 0.113 & 0.093 & 0.090 & 0.093 & 0.096 & & $88 \cdot 9$ & $90 \cdot 3$ & $86 \cdot 5$ & $84 \cdot 5$ & $81 \cdot 3$ \\
\hline 16 Amoebobacter pedioformis DSM $3802^{\mathrm{T}}$ & $0 \cdot 121$ & 0.091 & 0.088 & 0.119 & 0.099 & 0.093 & 0.081 & 0.095 & 0.096 & 0.091 & 0.085 & 0.085 & 0.086 & 0.075 & $0 \cdot 120$ & & $91 \cdot 6$ & $87 \cdot 7$ & $84 \cdot 1$ & $83 \cdot 0$ \\
\hline 17 Thiocystis violacea DSM $207^{\mathrm{T}}$ & $0 \cdot 114$ & 0.090 & 0.081 & 0.097 & 0.059 & 0.093 & 0.080 & 0.087 & 0.089 & 0.093 & 0.079 & 0.083 & 0.081 & 0.078 & $0 \cdot 104$ & 0.089 & & $88 \cdot 8$ & $86 \cdot 4$ & $84 \cdot 6$ \\
\hline 18 Ectothiorhodospira shaposhnikovii DSM $243^{T}$ & 0.144 & $0 \cdot 108$ & $0 \cdot 116$ & 0.121 & $0 \cdot 114$ & 0.141 & 0.123 & 0.128 & 0.139 & 0.135 & 0.117 & $0 \cdot 120$ & $0 \cdot 121$ & $0 \cdot 114$ & $0 \cdot 149$ & $0 \cdot 134$ & $0 \cdot 122$ & & 88.9 & $84 \cdot 1$ \\
\hline 19 Halorhodospira halophila DSM $244^{T}$ & $0 \cdot 167$ & $0 \cdot 141$ & $0 \cdot 146$ & 0.148 & $0 \cdot 148$ & $0 \cdot 164$ & $0 \cdot 150$ & $0 \cdot 168$ & $0 \cdot 169$ & 0.171 & $0 \cdot 152$ & $0 \cdot 158$ & $0 \cdot 161$ & 0.149 & $0 \cdot 174$ & 0.179 & $0 \cdot 150$ & $0 \cdot 120$ & & $81 \cdot 5$ \\
\hline 20 Escherichia coli & $0 \cdot 194$ & 0.177 & $0 \cdot 172$ & $0 \cdot 185$ & $0 \cdot 176$ & $0 \cdot 197$ & 0.187 & 0.196 & $0 \cdot 199$ & $0 \cdot 196$ & $0 \cdot 183$ & $0 \cdot 191$ & $0 \cdot 186$ & 0.174 & 0.215 & $0 \cdot 193$ & 0.172 & 0.179 & 0.213 & \\
\hline
\end{tabular}




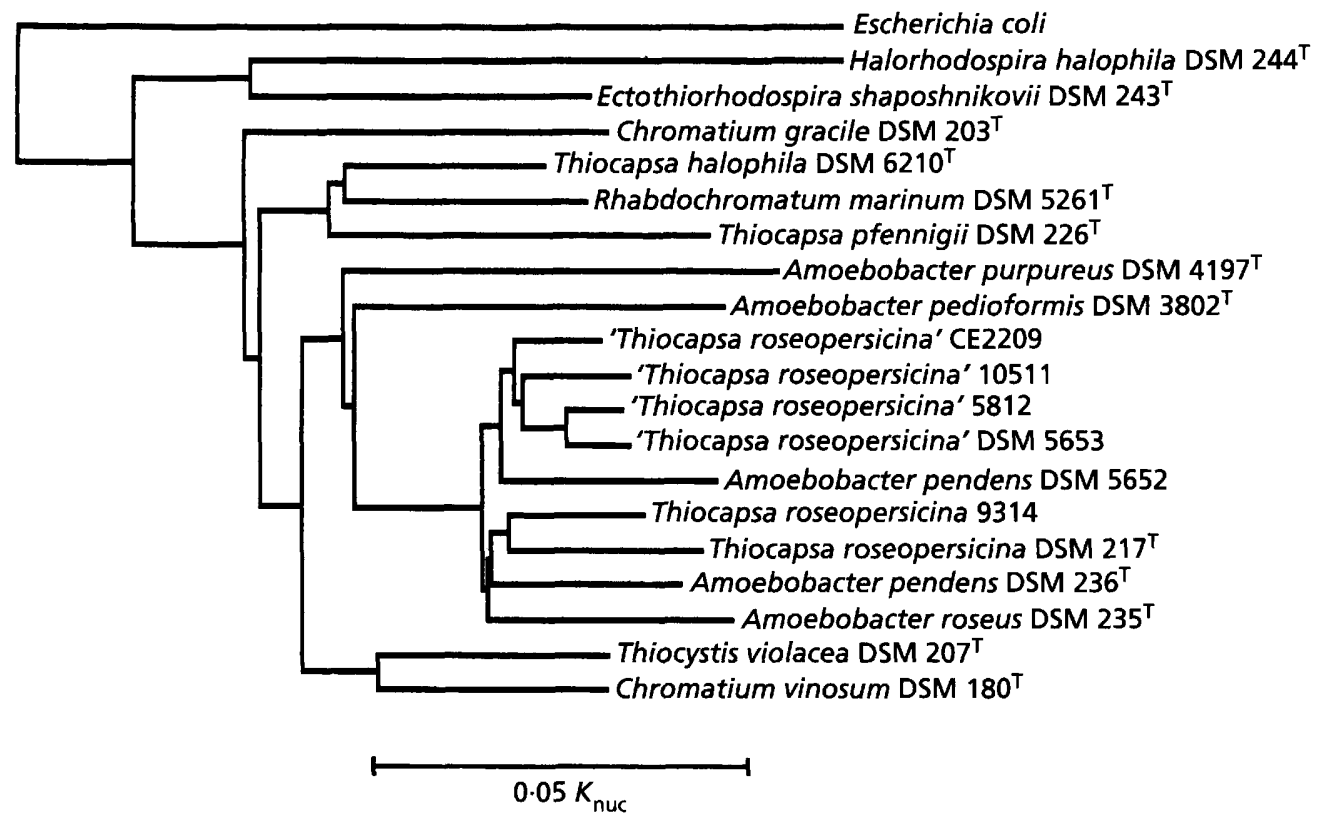

Fig. 1. Phylogenetic tree showing the relationships on the basis of 165 rDNA sequence similarity of strains belonging to the genera Thiocapsa and Amoebobacter together with other purple sulfur bacteria and Escherichia coli as reference organisms. Strain numbers and deposition numbers of the $16 \mathrm{~S}$ rDNA sequences (in brackets) of reference strains not included in Table 1 are as follows: Thiocystis violacea DSM 207 ${ }^{\top}$ (Y11315), Chromatium vinosum DSM 180 (M26629), Chromatium gracile DSM 203 ${ }^{\top}$ (X93473), Rhabdochromatium marinum DSM 5261 ${ }^{\top}$ (84316), Ectothiorhodospira shaposhnikovii DSM 243' (M59151), Halorhodospira halophila DSM 244 (M26630), Escherichia coli (K02555).

Table 3. Differential phenotypic traits of the genera Thiocapsa, Amoebobacter and Thiolamprovum

Data from references cited in Table 1. Bchl, bacteriochlorophyll; sp, spirilloxanthin; ok, okenone. Substrates used by all strains $(+)$, some strains $(+/-)$ or not used $(-)$.

\begin{tabular}{|c|c|c|c|}
\hline Characteristic & Thiocapsa & Amoebobacter & Thiolamprovum \\
\hline Natural habitat & $\begin{array}{l}\text { Water/mud from } \\
\text { freshwater to marine } \\
\text { environments }\end{array}$ & Stratified lakes & Wastewater ponds \\
\hline Aggregate pattern & $\begin{array}{l}\text { Tetrads, small } \\
\text { irregular aggregates }\end{array}$ & Clumps of up to 40 cells & Platelets \\
\hline Cell morphology & Spherical & Spherical/oval & Spherical/oval \\
\hline Cell size $(\mu \mathrm{m})$ & $1 \cdot 0-3 \cdot 0$ & $1.9-3.8 \times 2.0-4.5$ & $2 \cdot 0 \times 2 \cdot 0-3 \cdot 0$ \\
\hline Gas vesicles & $+1-$ & + & + \\
\hline $\mathrm{Bchl} /$ carotenoid & Bchl $a /$ sp, ok & Bchl $a /$ ok & Bchl $a / \mathrm{sp}$ \\
\hline Internal membranes & Vesicular & Vesicular & Vesicular \\
\hline $\mathrm{G}+\mathrm{C}$ content $(\mathrm{mol} \%)$ & $63 \cdot 3-66 \cdot 3$ & $63 \cdot 4-64 \cdot 1$ & $64 \cdot 5-66 \cdot 5$ \\
\hline \multicolumn{4}{|c|}{ Substrates used: } \\
\hline Sulfide & + & + & + \\
\hline Thiosulfate & + & + & + \\
\hline Propionate & + & + & - \\
\hline Pyruvate & + & + & + \\
\hline Malate & + & - & - \\
\hline
\end{tabular}


Table 4. Differential phenotypic traits of the type strains of the recognized species of the genus Thiocapsa

Data from references given in Table 1 and this study. See Table 3 legend for symbols and abbreviations

\begin{tabular}{|c|c|c|c|}
\hline Characteristic & $\begin{array}{c}\text { Thiocapsa } \\
\text { roseopersicina } \\
\text { (DSM 217 })\end{array}$ & $\begin{array}{l}\text { Thiocapsa pendens } \\
\text { (DSM 236 }\end{array}$ & $\begin{array}{c}\text { Thiocapsa rosea } \\
\text { (DSM 235 })\end{array}$ \\
\hline Cell morphology & Spherical & Spherical & Spherical \\
\hline Cell size $(\mu \mathrm{m})$ & $1 \cdot 0-3 \cdot 0$ & $1 \cdot 5-2 \cdot 0$ & $2 \cdot 0-3 \cdot 0$ \\
\hline Gas vesicles & No & Yes & Yes \\
\hline Bchl/carotenoid & Bchl $a / \mathrm{sp}$ & $\operatorname{Bchl} a / \mathrm{sp}$ & $\operatorname{Bchl} a / \mathrm{sp}$ \\
\hline $\mathrm{G}+\mathrm{C}$ content $(\mathrm{mol} \%)$ & $65 \cdot 3$ & $65 \cdot 3$ & $64 \cdot 3$ \\
\hline $\mathrm{SO}_{4}^{2-}$-assimilation & + & - & - \\
\hline Chemotrophic growth & + & - & + \\
\hline \multicolumn{4}{|l|}{ Substrates used: } \\
\hline Sulfide & + & + & + \\
\hline Thiosulfate & + & + & + \\
\hline Formate & - & - & - \\
\hline Acetate & + & + & + \\
\hline Propionate & + & + & + \\
\hline Pyruvate & + & + & + \\
\hline Malate & + & + & - \\
\hline Succinate & + & - & - \\
\hline Fumarate & + & - & - \\
\hline Glucose & - & + & - \\
\hline Fructose & + & - & + \\
\hline Glycerol & + & - & - \\
\hline
\end{tabular}

of the genus Thiocapsa; Thiocapsa roseopersicina (the type species), Thiocapsa pfennigii and Thiocapsa halophila, which have been classified into the genus Thiocapsa on the basis of morphological properties (non-motile cocci with internal sulfur globules). The sequence differences, however, do not merit the grouping of these species within one genus. Therefore, Thiocapsa pfennigii and Thiocapsa halophila have to be removed from the genus Thiocapsa, the name of which will stay with the type species, Thiocapsa roseopersicina. A formal taxonomic transfer will not be proposed at this stage, because the exact relationship of these two bacteria with other members of the Chromatiaceae is presently not established.

The second major consequence of our results is the close phylogenetic relationships between Thiocapsa roseopersicina and A. roseus as well as other Amoebobacter species. Thiocapsa roseopersicina may have evolved from an ancestor containing gas vesicles by loss of this property; some strains may still contain genes for the production of gas vesicles and may even be able to form such vesicles under certain, so far unrecognized, conditions. Nonetheless, it is obvious that the formation of gas vesicles is not of taxonomic relevance at the genus level. Other phenotypic features have to be considered to separate $A$. purpureus, $A$. pedioformis and representatives of the 'Thiocapsa roseopersicina group'. Morphological traits such as cell morphology, aggregate patterns and the presence or absence of a strong slime capsule (Table 3 ) may be considered for characterizing the species. Therefore, on the basis of genetic and phenotypic properties, we propose to maintain the genus Amoebobacter, with $A$. purpureus as the new type species and to transfer $A$. pedioformis to Thiolamprovum pedioforme gen. nov., comb. nov.

The 'Thiocapsa roseopersicina group' is represented by three species: Thiocapsa roseopersicina, A.pendens and $A$. roseus. The strains studied do form two sub-groups, corresponding to the three type strains of the species and a second group of isolates tentatively assigned to Thiocapsa roseopersicina and $A$. pendens, respectively (Table 1, Fig. 1).

Apart from the formation of gas vesicles, which could be of taxonomic importance at the species level, some physiological features such as substrate utilization and chemolithoautotrophic growth capacities separate the three existing species (Table 4). All strains of Thiocapsa roseopersicina characteristically use hydrogen, glycerol, fructose, succinate, fumarate and malate as substrates. $A$. pendens and $A$. roseus do not use hydrogen, glycerol, succinate or fumarate (Table 4). In addition, $A$. roseus does not use malate, whereas $A$. 
pendens is the only species able to use glucose but not fructose. Thiocapsa roseopersicina and $A$. roseus can grow chemolithoautotrophically with oxygen in the dark (De Wit \& van Gemerden, 1987; Kämpf \& Pfennig, 1980; Overmann \& Pfennig, 1992). The two strains classified as $A$. pendens exibited differences with regard to chemotrophic growth. A. pendens DSM $236^{\mathrm{T}}$ is unable to grow chemotrophically (Kämpf \& Pfennig, 1980) whereas 'Amoebobacter pendens' DSM 5652 grows chemolithoautotrophically (Overmann \& Pfennig, 1992). This strain had been originally and tentatively identified as a Thiocapsa roseopersicina (Caumette et al., 1985), but was later reclassified as $A$. pendens (Eichler \& Pfennig, 1986), although it was different from the type strain of this species with regard to chemotrophic growth and gas vesicles were not always present.

Because 'it is the presence or absence of phenotypic coherency among strains that should be the deciding factor' (Stackebrandt \& Goebel, 1994), we propose to maintain these three existing species and to consider them as members of the genus Thiocapsa, with Thiocapsa roseopersicina as the type species. Therefore, we propose to transfer $A$. pendens to Thiocapsa pendens comb. nov. and $A$. roseus to Thiocapsa rosea comb. nov.

Within this genus, strains 5811 (DSM 5653) and 5812 were mentioned as Thiocapsa roseopersicina forma specialis (Caumette et al., 1985), because they contain okenone as the major carotenoid, while the other phenotypic traits were identical to those of Thiocapsa roseopersicina (Table 4). They are closely related genetically (Table 2), and could probably be described as a new species within the genus Thiocapsa on the basis of genetic relationship and pigment composition. Nevertheless, they both are closely related to the Thiocapsa sp. strain 10511 (97.4 and $97.3 \%$ sequence similarity, respectively), which contains spirilloxanthin as the main carotenoid. A decision at the species level would require DNA-DNA reassociation studies and is therefore not proposed at the present level of our knowledge. A similar uncertainty that could possibly be resolved by hybridization studies is the exact species assignment of other strains, which have been tentatively identified as belonging to Thiocapsa roseopersicina (CE2209, 9314, 10511) and A. pendens (DSM 5652). However, knowledge of genetic relationships and phenotypic features undoubtedly permit an assignment of these strains to the genus Thiocapsa.

Emended descriptions of the genera Thiocapsa and Amoebobacter are given, and the following taxonomic changes are proposed : transfer of Amoebobacter roseus (the former type species of the genus Amoebobacter) to the genus Thiocapsa and description as a new combination, Thiocapsa rosea comb. nov.; transfer of Amoebobacter pendens to the genus Thiocapsa and description as a new combination, Thiocapsa pendens comb. nov.; definition of Amoebobacter purpureus as the new type species of the genus Amoebobacter; removal of Thiocapsa pfennigii and Thiocapsa halophila from the genus Thiocapsa; and transfer of Amoebobacter pedioformis to the new genus Thiolamprovum gen. nov. as Thiolamprovum pedioforme comb. nov.

\section{Emended description of the genus Thiocapsa Winogradsky $1888,84^{\mathrm{AL}}$}

Thiocapsa (Thi.o.cap'sa. Gr. n. thios sulfur; L. n. capsa box; M.L. fem. n. Thiocapsa sulfur box).

Cells are spherical, $1 \cdot 0-3 \cdot 0 \mu \mathrm{m}$ in diameter, diplococci before multiplication by binary fission and are nonmotile. Tetrads may be formed after consecutive division in two perpendicular planes. Individual cells are surrounded by a strong slime capsule. May contain gas vesicles. Gram-negative. Internal photosynthetic membrane system of vesicular type containing the photosynthetic pigments bacteriochlorophyll $a$ and carotenoids. Phototrophic under anoxic conditions in the light, may be chemoautotrophic or mixotrophic under micro-oxic to oxic conditions in the dark. Capable of photolithoautotrophic growth with sulfide, thiosulfate and sulfur as electron donor. Elemental sulfur globules are transiently stored inside the cells, final oxidation product is sulfate. May require vitamin $\mathrm{B}_{12}$. The $\mathrm{G}+\mathrm{C}$ content of the DNA is $63 \cdot 3-66 \cdot 3 \mathrm{~mol} \%$ (Bd). Type species is Thiocapsa roseopersicina.

\section{Description of Thiocapsa rosea comb. nov. (Amoebobacter roseus Winogradsky 1888, 77}

Thiocapsa rosea (ro'se.a. L. adj. rosea rosy, rosecoloured, pink).

The description is the same as that given by Winogradsky (1888) and Pfennig (1989b). Neotype strain is DSM 235 (= strain 6611, Davis).

\section{Description of Thiocapsa pendens comb. nov. (Amoebobacter pendens Pfennig and Trüper 1971, 13 ${ }^{\mathrm{AL}}$; Rhodothece pendens Molisch 1906, 230)}

Thiocapsa pendens (pen'dens. L. part. adj. pendens hanging).

The description is the same as that given by Pfennig, (1989b) and Pfennig \& Trüper (1971a). Neotype strain is DSM 236 (= strain 1314, Klein-Kalden).

\section{Emended description of the genus Amoebobacter Winogradsky 1888, $71^{\mathrm{AL}}$}

Amoebobacter (A.moe.bo.bac'ter. Gr. n. amoebe change, transformation; M.L. n. bacter a rod; M.L. masc. n. Amoebobacter changeable rod).

Cells are nearly spherical to oval, 1.9-3.8 $\times 2.0-4.5 \mu \mathrm{m}$ in size, may occur in irregular aggregates of up to 40 cells, multiplication by binary fission, non-motile, Gram-negative. Internal photosynthetic membrane system of vesicular type containing the photosynthetic 
pigments bacteriochlorophyll $a$ and carotenoids. Phototrophic under anoxic conditions in the light, may be chemoautotrophic or mixotrophic under micro-oxic conditions in the dark. Capable of photolithoautotrophic growth with sulfide, thiosulfate and elemental sulfur as electron donor, elemental sulfur globules are transiently stored inside the cells, final oxidation product is sulfate. Assimilatory sulfate reduction lacking. The $\mathrm{G}+\mathrm{C}$ content of the DNA is 63.4-64.1 mol \% (Bd). Type species is Amoebobacter purpureus.

\section{Description of Amoebobacter purpureus Eichler and Pfennig 1988}

Amoebobacter purpureus (pur.pur'e.us. L. masc. adj. purpureus purple or purple-red).

The description is the same as that given by Eichler \& Pfennig (1988). Type strain is DSM $4197^{\mathrm{T}}$ (=strain ThSchl2 ${ }^{\mathrm{T}},=$ Schleinsee $^{\mathrm{T}}$ ).

\section{Description of Thiolamprovum gen. nov.}

Thiolamprovum (Thi.o.lam.pro'vum. Gr. n. thios sulfur; Gr. n. lampros bright, brilliant; L. n. ovum egg; M.L. masc. n. Thiolamprovum bright egg with sulfur).

Cells nearly spherical to oval, $2 \times 2-3 \mu \mathrm{m}$ in size, may occur in regular platelets of 4-16 cells, multiplication by binary fission, non-motile, Gram-negative. Internal photosynthetic membrane system of vesicular type containing the photosynthetic pigments bacteriochlorophyll $a$ and carotenoids. Phototrophic under anoxic conditions, may be chemoautotrophic or mixotrophic under micro-oxic conditions in the dark. Capable of photolithoautotrophic growth with sulfide, thiosulfate and elemental sulfur as electron donor, elemental sulfur globules are transiently stored inside the cells, final oxidation product is sulfate. Assimilatory sulfate reduction lacking. The $\mathrm{G}+\mathrm{C}$ content of the DNA is $64.5-66.5 \mathrm{~mol} \%(\mathrm{Bd})$. Type species is Thiolamprovum pedioforme.

\section{Description of Thiolamprovum pedioforme comb. nov. (Amoebobacter pedioformis Eichler and Pfennig 1986)}

Thiolamprovum pedioforme (pe.di.o.for'me. Gr. $\mathrm{n}$. pedion a plain, a flat area; L. n. forma shape; M.L. neut. adj. pedioforme flat-shaped).

The description is the same as that given by Eichler \& Pfennig (1986). Type strain is DSM $3802^{\mathrm{T}}$ (=strain

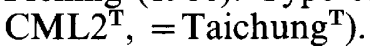

\section{REFERENCES}

Bavendamm, W. (1924). Die farblosen und roten Schwefelbakterien. Fischer, Jena.

Caumette P. (1986). Phototrophic sulfur bacteria and sulfatereducing bacteria causing red waters in a shallow brackish coastal lagoon (Prévost Lagoon, France). FEMS Microbiol Ecol 38, 113-124.
Caumette, P., Schmidt, K., Biebl, H. \& Pfennig, N. (1985). Characterization of a Thiocapsa strain containing okenone as major carotenoid. Syst Appl Microbiol 6, 132-136.

Caumette, P., Baulaigue, R. \& Matheron, R (1991). Thiocapsa halophila sp. nov., a new halophilic phototrophic purple sulfur bacterium. Arch Microbiol 155, 170-176.

Caumette, P., Imhoff, J. F., Süling, J. \& Matheron, R. (1997). Chromatium glycolicum sp. nov., a moderately halophilic purple sulfur bacterium that uses glycolate as substrate. Arch Microbiol 167, 11-18.

De Weerd, K. A., Mandelco, L., Tanner, R. S., Woese, C. R. \& Suflita, J. M. (1990). Desulfomonile tiedjei gen. nov. and sp. nov., a novel anaerobic, dehalogenating, sulfate-reducing bacterium. Arch Microbiol 154, 23-30.

De Wit, R. \& van Gemerden, H. (1987). Chemolithotrophic growth of the phototrophic purple sulfur bacterium Thiocapsa roseopersicina. FEMS Microbiol Ecol 45, 117-126.

Dilling, W., Liesack, W. \& Pfennig, N. (1995). Rhabdochromatium marinum gen. nom. rev., sp. nov., a purple sulfur bacterium from salt marsh microbial mat. Arch Microbiol 164, 125-131.

Eichler, B. \& Pfennig, N. (1986). Characterization of a new platelet-forming purple sulfur bacterium, Amoebobacter pedioformis sp. nov. Arch Microbiol 146, 295-300.

Eichler, B. \& Pfennig, N. (1988). A new purple sulfur bacterium from stratified freshwater lakes, Amoebobacter purpureus sp. nov. Arch Microbiol 149, 395-400.

Felsenstein, J. (1989). PHYLIP - phylogenetic inference package (version 3.2). Cladistics 5, 164-166.

Fowler, V. J., Pfennig, N., Schubert, W. \& Stackebrandt, E. (1984). Towards a phylogeny of phototrophic bacteria - 16S rRNA oligonucleotide cataloguing of 11 species of Chromatiaceae. Arch Microbiol 139, 382-387.

Guyoneaud, R., Matheron, R., Baulaigue, R., Podeur, K., Hirschler, A. \& Caumette, P. (1996). Anoxygenic phototrophic bacteria in eutrophic coastal lagoons of the French Mediterranean and Atlantic coasts (Prévost Lagoon, Arcachon Bay, Certes Fishponds). Hydrobiologia 329, 33-43.

Guyoneaud, R., Matheron, R., Liesack, W., Imhoff, J. F. \& Caumette, P. (1997). Thiorhodococcus minus gen. nov., sp. nov., a new purple sulfur bacterium isolated from coastal lagoon sediments. Arch Microbiol 168, 16-23.

Imhoff, J. F. (1984). Reassignment of the genus Ectothiorhodospira Pelsh 1936 to a new family Ectothiorhodospiraceae fam. nov., and emended description of the Chromatiaceae Bavendamm 1924. Int J Syst Bacteriol 34, 338-339.

Imhoff, J. F. \& Suling, J. (1996). The phylogenetic relationship among Ectothiorhodospiraceae. A re-evaluation of their taxonomy on the basis of rDNA analyses. Arch Microbiol 165, 106-113.

Jukes, T. H. \& Cantor, C. R. (1969). Evolution of protein molecules. In Mammalian Protein Metabolism, pp. 21-132. Edited by H. M. Munro. New York: Academic Press.

Kămpf, C. \& Pfennig, N. (1980). Capacity of Chromatiaceae for chemotrophic growth. Specific respiration rates of Thiocystis violacea and Chromatium vinosum. Arch Microbiol 127, 125-135.

Mandel, M., Leadbetter, E. R., Pfennig, N. \& Trüper, H. G. (1971). Deoxyribonucleic acid base compositions of phototrophic bacteria. Int J Syst Bacteriol 21, 222-230.

Mullis, K. B. \& Faloona, F. (1987). Specific synthesis of DNA in vitro via a polymerase-catalysed chain reaction. Methods Enzymol 155, 335-350. 
Overmann, J. \& Pfennig, N. (1992). Continuous chemotrophic growth and respiration of Chromatiaceae species at low oxygen concentrations. Arch Microbiol 158, 59-67.

Overmann, J. \& Tuschak, C. (1997). Phylogeny and molecular fingerprinting of green sulfur bacteria. Arch Microbiol 167, 302-309.

Pfennig, N. (1989a). Genus IV. Thiocapsa Winogradsky 1888, $84^{\mathrm{AL}}$. In Bergey's Manual of Systematic Bacteriology, vol. 3, pp. 1645-1647. Edited by J. T. Staley, M. P. Bryant, N. Pfennig \& J. G. Holt. Baltimore: Williams \& Willkins.

Pfennig, N. (1989b). Genus VIII. Amoebobacter Winogradsky $1888,71^{\mathrm{AL}}$. In Bergey's Manual of Systematic Bacteriology, vol. 3, pp. 1651-1652. Edited by J. T. Staley, M. P. Bryant, N. Pfennig \& J. G. Holt. Baltimore: Williams \& Willkins.

Pfennig, N. \& Trüper, H. G. (1971a). New nomenclatural combinations in the phototrophic sulfur bacteria. Int $J$ Syst Bacteriol 21, 11-14.

Pfennig, N. \& Truper, H. G. (1971b). Type and neotype strains of the phototrophic bacteria maintained in pure culture. Int $J$ Syst Bacteriol 21, 19-24.

Pfennig, N. \& Trüper H. G. (1992). The family Chromatiaceae. In
The Prokaryotes pp. 3200-3221. Edited by A. Balows, H. G. Trüper, M. Dworkin, W. Harder \& K. H. Schleifer. New York: Springer.

Sanger, F., Nicklen, S. \& Coulson, A. R. (1977). DNA sequencing with chain-terminating inhibitors. Proc Natl Acad Sci USA 74, 5463-5467.

Stackebrandt, E. \& Goebel, B. M. (1994). Taxonomic note: a place for DNA-DNA reassociation and 16S rRNA sequence analysis in the present species definition in bacteriology. Int $J$ Syst Bacteriol 44, 846-849.

Thompson, J. D., Higgins, D. G. \& Gibson, T. J. (1994). CLUSTAL $\mathrm{W}$ : improving the sensitivity of progressive multiple sequence alignment through sequence weighting position-specific gap penalties and weight matrix choice. Nucleic Acids Res 22, 4673-4680.

Wahlund, T. M., Woese, C. R., Castenholz, R. W. \& Madigan, M. T. (1991). A thermophilic green sulfur bacterium from New Zealand hot springs, Chlorobium tepidum sp. nov. Arch Microbiol 156, 81-90.

Winogradsky, S. (1888). Beiträge zur Morphologie und Physiologie der Bakterien, Heft 1. Zur Morphologie und Physiologie der Schwefelbakterien. Leipzig: Felix. 